\title{
Protective Effects of Nothopanax scutellarium on Hepatotoxicity of Copper(II) Induced to Experimental Rats
}

\author{
Sri Wahyuni Nasution ${ }^{1,2 *}$, Eti Yerizel ${ }^{3}$, Zulkarnain Chaidir $^{4}$, Rahmiana Zein ${ }^{4,5}$ \\ ${ }^{1}$ Doctoral Student of Postgraduate Chemistry Science, Faculty of Mathematics and Natural Sciences, Andalas University, \\ Padang, Indonesia; ${ }^{2}$ Department of Tropical Medicine, Faculty of Medicine, University of Prima Indonesia, Medan, Indonesia; \\ ${ }^{3}$ Department of Biochemistry, Faculty of Medicine, Andalas University, Padang, Indonesia; ${ }^{4}$ Department of Chemistry, Faculty \\ of Mathematics and Natural Sciences, Andalas University, Padang, Indonesia; ${ }^{5}$ Department of Environmental Analytical \\ Chemistry, Faculty of Mathematics and Natural Sciences, Andalas University, Padang, Indonesia
}

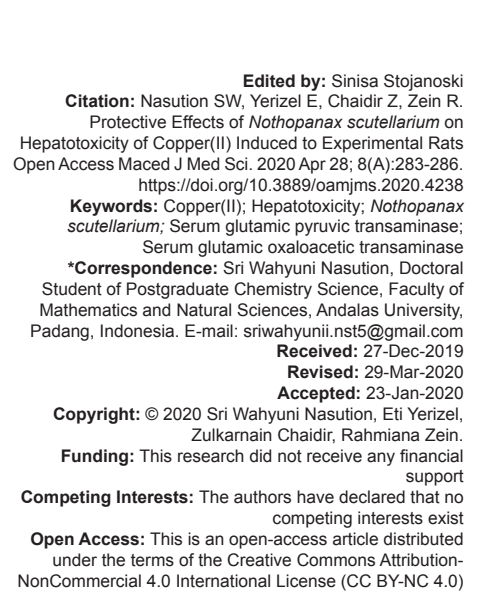

Abstract

BACKGROUND: Nothopanax scutellarium is a plant containing substance such as flavonoids, saponins, amygdalin peroxidase, calcium oxalate, polyphenols, proteins, fats, calcium, phosphorus, iron, and Vitamins A, B1, and C.

AIM: The purpose of this study was to investigate the hepatoprotective effect of $N$. scutellarium leaves against rats induced with $\mathrm{Cu}(\mathrm{II})$

MATERIALS AND METHODS: Three groups of female Wistar rats (Rattus norvegicus) within the range of age 2.5-3 months were used. Each group was composed of three female rats. Group I was a control given a normal diet and distilled water. Group II was exposed to $1000 \mathrm{mg} / \mathrm{L}$ of $\mathrm{Cu}(\mathrm{II})$ solution with a dosage of $1 \mathrm{~mL} \times \mathrm{bw} / 200 \mathrm{~g}$. Group III was given $5 \mathrm{~mL}$ of antidote $N$. scutellarium extract for 7 days then exposed to $1000 \mathrm{mg} / \mathrm{L}$ of Cu(II) solution with a dosage of $1 \mathrm{~mL} \times$ bw/200 g. The blood test (malondialdehyde [MDA], serum glutamic oxaloacetic transaminase [SGOT], and serum glutamic pyruvic transaminase [SGPT]) and histopathology of liver were examined after $5 \mathrm{~h}$ of exposure.

RESULTS: The administration of $N$. scutellarium as hepatoprotective in experimental rats resulted in significan reductions in MDA, SGOT, and SGPT as much as $33.87 \%, 51.14 \%$, and $12.57 \%$, respectively.

CONCLUSION: This study concluded that indicates the increase of the parameters of liver function and stress oxidative parameters including MDA, SGOT, and SGPT.

\section{Introduction}

Copper $(\mathrm{Cu}(\mathrm{II}))$ is a mineral that is essential for physical and mental health. In the case of an increase or overuse of $\mathrm{Cu}(\mathrm{II})$, it can cause $\mathrm{Cu}(\mathrm{II})$ poisoning. $\mathrm{Cu}(\mathrm{II})$ commonly present in foods, hot water pipes, malnutrition tablets, birth control pills, etc. [1]. Excessive copper exposure ( $>2 \mathrm{mg} / \mathrm{L}$ ) in drinking water causes poisoning to humans and damages the environment [2]. Many methods are used to remove toxic metal ions from wastewater such as adsorption, precipitation, evaporation, electroplating, ion exchange, and membrane processes. Exposure to $\mathrm{Cu}(\mathrm{II})$ in experimental rats caused changes in the level of biochemical parameters of malondialdehyde (MDA), serum glutamic pyruvic transaminase (SGPT), and serum glutamic oxaloacetic transaminase (SGOT). Biosorption is one of the most effective and lowcost biotechnology innovation processes to remove heavy metals from aqueous solutions. The use of microorganisms (especially bacteria, algae, yeast, and fungi) as biosorbents can remove heavy metals widely used [3-6].
Nothopanax scutellarium has the potential to utilize as an efficient material adsorbent for removing $\mathrm{Cu}$ (II) metal ions [7]. N. scutellarium contains compounds such as alkaloids, tannins, saponins, and flavonoids [8]. Leman tread leaves are also used as vegetables to enhance the delicacy of the taste of cooking. The aim of the research was to investigate the effect of the hepatoprotective of $N$. scutellarium leaves against rats induced with $\mathrm{Cu}(\mathrm{II})$.

\section{Materials and Methods}

\section{Preparation for experimental rats}

Three groups of female Wistar rats (Rattus norvegicus) within the range of age 2.5-3 months were used. Each group was composed of three female rats. Group I was a control given a normal diet and distilled water. Group II was exposed to $1000 \mathrm{mg} / \mathrm{L}$ of $\mathrm{Cu}(\mathrm{II})$ solution with a dosage of $1 \mathrm{~mL} \times \mathrm{bw} / 200 \mathrm{~g}$. 
Group III was given $5 \mathrm{~mL}$ of antidote $N$. scutellarium extract for 7 days then exposed to $1000 \mathrm{mg} / \mathrm{L}$ of $\mathrm{Cu}(\mathrm{II})$ solution with a dosage of $1 \mathrm{~mL} \times \mathrm{bw} / 200 \mathrm{~g}$. After 5 $\mathrm{h}$, the blood test was drawn and analyzed for stress oxidative parameters and parameter function of the liver (MDA, SGOT, and SGPT).

\section{Measurement of MDA}

Provided three test tubes containing blanks (distilled water), standard, serum (sample) $0.5 \mathrm{~mL}$. Add $2.5 \mathrm{ml}$ of $5 \%$ trichloroacetic acid each. Mix using a vortex mixer, centrifuge for $10 \mathrm{~min}$ at $2000 \mathrm{rpm}$. Each pipette $1.5 \mathrm{~mL}$ filtrate, put into a tube in accordance with the label. Add $1.5 \mathrm{~mL}$ Na each. Thiobarbituric acid mix with a vortex mixer, heat it in a water bath for $30 \mathrm{~min}$. Cool, read the adsorbent with spectrophotometers at a wavelength of $530 \mathrm{~nm}$.

\section{Measurement of SGPT levels in serum}

Arranged tubes on shelves that have been provided, then labeled, starting samples 1, 2, 3, etc. Pipette $100 \mu \mathrm{l}$ serum 1 input into the S1 tube, added $1000 \mu \mathrm{l}$ reagent 1 (Tris $\mathrm{pH} 7.15100 \mathrm{mmol} / \mathrm{L}$, L-alanine $500 \mathrm{mmol} / \mathrm{L}$, lactate dehydrogenase [(LDH) $\geq 1700 \mathrm{U} / \mathrm{L}])$, mixed, incubated at room temperature for $5 \mathrm{~min}$, added reagent 2 of $250 \mu$ (2-oxo-glutaric $15 \mathrm{mmol} / \mathrm{L}, \mathrm{NADH}$ $0.18 \mathrm{mmol} / \mathrm{L}$, pyridoxal-5-phosphate $0.09 \mathrm{mmol} / \mathrm{L}$, buffer $\mathrm{pH} 9.60 .7 \mathrm{mmol} / \mathrm{L})$, mixed, and read the absorbance after 1,2 , and $3 \mathrm{~min}$, continued for the tube (sample 2, 3, etc.).

\section{Measurement of SGOT levels in serum}

The tubes are arranged in a rack that has been provided, then labeled, starting samples 1, 2, 3, etc. Then, a $100 \mu$ l serum 1 pipette is input into the $S 1$ tube, $1000 \mu \mathrm{l}$ Tris reagent is added $\mathrm{pH} 7.6580 \mathrm{mmol} / \mathrm{L}$, L-aspartate $240 \mathrm{mmol} / \mathrm{L}$, malate dehydrogenase a600 U/L, LDH $\geq 900 \mathrm{U} / \mathrm{L}$ mixed, incubated at room temperature for $5 \mathrm{~min}$, added reagent 2 (2-oxoglutaric $12 \mathrm{mmol} / \mathrm{L}, \mathrm{NADH}$ $0.18 \mathrm{mmol} / \mathrm{L}$ pyridoxal-5-phosphate $0.09 \mathrm{mmol} / \mathrm{L}$, buffer $\mathrm{pH} 9.60,7 \mathrm{mmol} / \mathrm{L})$, as much as $250 \mu \mathrm{l}$, mixed, and read the absorbance after 1,2 , and 3 min.

\section{Results}

\section{levels in serum \\ Examination of MDA, SGOT, and SGPT}

Effect of $N$. scutellarium leaf as an antidote to liver function parameters and pre-treatment effects with $N$. scutellarium leaf antidote on MDA, SGPT, and SGOT levels is shown in Table 1.

\section{Histological analysis}

Table 1: The mean level of MDA, SGOT, and SGPT

\begin{tabular}{lllll}
\hline No. & Parameters & $\begin{array}{l}\text { Group 1 } \\
\text { (Control) }\end{array}$ & Group 2 (Cu (II)) treatment) & Group 3 (Antidote+Cu (II)) \\
\hline 1. & MDA (mg/dl) & 3.61 & 8.06 & $5.33^{*}$ \\
2. & SGOT (U/L) & 111.987 & 123.97 & $60.57^{*}$ \\
3. & SGPT (U/L) & 25.88 & 92.5 & $80.87^{*}$ \\
\hline \multicolumn{2}{l}{ MDA: Malondialdehyde, SGOT: Serum glutamic oxaloacetic transaminase, SGPT: Serum glutamic pyruvic }
\end{tabular}

The protective effect of $N$. scutellarium leaf powder on liver damage caused by the toxicity of $\mathrm{Cu}(\mathrm{II})$ ions is histopathologically shown in Figure 1.

Figure 1 indicates the effect of $\mathrm{Cu}(\mathrm{II})$ and $N$. scutellarium extract induction on the liver of

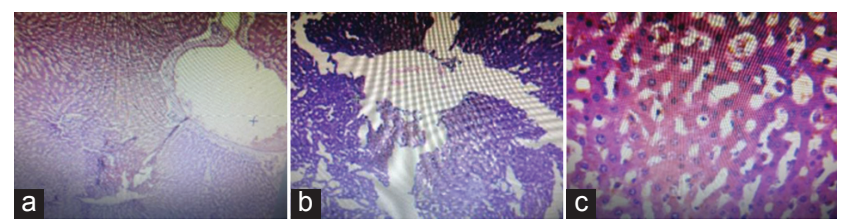

Figure 1: Histopathology of liver on experimental rats, (a) control; (b) $\mathrm{Cu}$ (II) ion induction without an antidote, (c) Nothopanax scutellarium extract with $\mathrm{Cu}(\mathrm{II})$ induction, $\times 40$

experimental rats. It showed that the $\mathrm{Cu}(\mathrm{II})$ induction gave significant damage to the liver marked by broadening of central vein and some of the hepatocytes experiencing cloudy swelling (Figure 1b). Whereas, the antidote seems to have a protective effect toward the liver indicated by mild fatty formation although it has been induced by $\mathrm{Cu}(\mathrm{II})$ ion. The same result also has been reported by the previous research and stated that particular plant extract was able to reduce live damage due to $\mathrm{Cu}(\mathrm{II})$ poisoning [9].

\section{Discussion}

\section{Examination of MDA, SGOT, and SGPT levels in serum}

MDA level listed in Table 1 of Group 1 as control was $3.61 \mathrm{mg} / \mathrm{dl}$. After $\mathrm{Cu}(\mathrm{II})$ exposure, MDA increased to $8.06 \mathrm{mg} / \mathrm{dl}$ (Group II). The MDA level decreased after the experimental rats were induced by antidote from $N$. scutellarium leaves extract from $8.06 \mathrm{mg} / \mathrm{dl}$ to $5.33 \mathrm{mg} / \mathrm{dl}$. MDA is one of the most famous secondary products of lipid peroxidation that functions in biomaterials as an indicator of cell membrane damage. N. scutellarium contained flavonoids, saponins, alkaloids, proteins, fats, calcium, phosphorus, iron, Vitamins $A, B$, and $C$, calcium oxalate, peroxidase, amygdalin, and tannin $[10,11]$. Exposure to free radicals can cause oxidative stress. In the liver, this process causes impaired liver function. Oxidative stress compresses antioxidants [12]. Oxidative stress is a pathological condition, can cause abnormalities in the body one of the developments of liver damage. Many 
risk factors, including environmental pollution, alcohol, drugs, and irradiation, can cause oxidative stress in the liver. Antioxidants as a rational curative strategy to prevent and cure liver diseases involving oxidative stress. Natural antioxidants contained in edible plants or medicines have antioxidant benefits and free radical flushing and anti-inflammatory action, the basis for bioactivity and other health benefits [13].

As presented in Table 1, N. scutellarium extract decreased the level of SGPT and SGOT after the administration of $\mathrm{Cu}(\mathrm{II})$ in experimental rats. The increased levels of SGPT and SGOT levels in Group II were a sign of liver damage due to the exposure to $\mathrm{Cu}(\mathrm{II})$. The provision of $N$. scutellarium leaf protection can significantly lower SGOT and SGPT levels. $N$. scutellarium has a protective effect of flavonoids on copper toxicity and may be due to the chelating effect of $\mathrm{Cu}(\mathrm{II})$.

The previous study investigated the effect of Annona muricata leaf protection against $\mathrm{Cu}$ (II) toxicity induced in experimental mice. Rats were induced with $\mathrm{Cu}$ (II) as much as $1000 \mathrm{mg} / \mathrm{L}$ intraperitoneally lead to the increase of liver and kidney parameter function (SGOT, SGPT, urea, creatinine, and MDA). Histologic analysis of liver tissue after induced by $\mathrm{Cu}(\mathrm{II})$ showed central venous dilation, hepatocyte swelling, and necrosis. After being given $A$. muricata, the antidote can reduce the level of liver and kidney function parameters and oxidative stress in mice. Histologically, pre-treatment with $A$. muricata leaf antidote can reduce the effects of liver structure damage due to $\mathrm{Cu}(\mathrm{II})$ toxicity [9].

Liver profile for detecting liver disease, SGOT and SGPT, is sensitive markers of hepatocellular injury. Serum SGOT is found in various tissues, including heart, skeletal muscle, kidney, brain, pancreas, lung, leukocytes, and erythrocytes. SGPT is a metabolic enzyme released when damage occurs in hepatocytes [14]. The protective effect of $A$. muricata leaf against toxic $\mathrm{Cu}(\mathrm{II})$ induced in experimental mice intraperitoneally could increase in liver and kidney function parameters and oxidative stress parameters including SGOT, SGPT, urea, creatinine, and MDA. After being given A. muricata, the antidote can reduce the level of liver and kidney function parameters and oxidative stress in mice [15].

$\mathrm{Cu}(\mathrm{II})$ exposure caused changes in the level of biochemical parameters of MDA, SGPT, and SGOT. Pre-treatment with $N$. scutellarium leaf antidote was able to return the parameters of MDA, SGPT, and SGOT to normal. This means that $N$. scutellarium leaves antidote could reduce the toxic effects of $\mathrm{Cu}(\mathrm{II})$ toxicity in experimental rats. Pre-treatment with $N$. scutellarium antidote can reduce liver damage which may be due to the high content of antioxidants and free radical activity.

\section{Histological analysis}

Rats liver photomicrographs in the control group are shown in Figure 1a. Group II treatment with the addition of $\mathrm{Cu}$, in the picture above, shows that in this treatment, liver damage has occurred marked by lysis of venous central cells. Another damage is hepatocyte cell necrosis in the form of picnics, i.e., the cell nucleus (nucleus) looks more rounded, smaller and rounder size and karyolysis, i.e., the nucleus lysis is not visible, only the empty cavity is aborted by the membrane of the nucleus in Figure 2 and c. Group III treatment with the addition of the leaf tread after the administration of leman tread leaves resulted in histopathological improvement in liver cells in Figure 3.

Polyphenols and flavonoids have been known to have antioxidant, anti-inflammatory, hepatoprotective, antithrombotic, antiviral, and anticarcinogenic activities [16] Copper is an essential nutrient that reacts with a number of metalloenzymes involved in the formation of hemoglobin, carbohydrate metabolism, catecholamine biosynthesis, and cross-linking of collagen, elastin, and hair keratin. The ability of copper to cycle between the oxidation state of $\mathrm{Cu}(\mathrm{II})$ and the oxidation level of $\mathrm{Cu}(\mathrm{I})$ used by cuproenzyme is involved in redox reactions, this copper property is also potentially toxic because it can produce superoxide and hydroxyl radicals that can cause damage to various organs [17].

Copper can also accumulate in water and soil even to a higher degree and can stick to clothing and skin. Circulation or presence of copper in the body requires good functioning of the liver, bladder, and adrenal glands. If one of these organs is disrupted, the body is unable to excrete and utilize copper properly. Copper will accumulate in the liver, the effect can further cause the inability to excrete copper. Increased copper concentrations will cause accumulation in the brain, joints, and lungs, which will affect the structure and function of tissues [15].

\section{References}

1. Ashish B, Neeti K, Himanshu K. Copper toxicity: Acomprehensive study. Res J Recent Sci. 2013;2277:2502.

2. Saman K, Abida F, Danish DD, MI MM, Akif Z. Biosorption of copper(II) from aqueous solution using citrus sinensis peel and wood sawdust: Utilization in purification of drinking and waste water. IJRRAS. 2013;16:297-306

3. Zein R, Suhaili R, Earnestly F, Indrawati, Munaf E. Removal of $\mathrm{Pb}(\mathrm{II}), \mathrm{Cd}(\mathrm{II})$ and $\mathrm{Co}(\mathrm{II})$ from aqueous solution using Garcinia mangostana L. fruit shell. J Hazard Mater. 2010;181(1-3):52-6. https://doi.org/10.1016/j.jhazmat.2010.04.076 PMid:20627410

4. Zein R, Hidayat AD, Elfia M, Nazarudin N, Munaf E. Sugar palm Arenga pinnata Mer (Magnoliophyta) fruit shell as biomaterial to remove $\mathrm{Cr}(\mathrm{III}), \mathrm{Cr}(\mathrm{VI}), \mathrm{Cd}(\mathrm{II})$, and $\mathrm{Zn}(\mathrm{II})$ from aqueous solution. J Water Supply. 2014;63:553. https://doi.org/10.2166/ aqua.2014.120

5. Zein R. AIP Conference Proceedings, No. 2023 (020099); 2018.

6. Abbas SH, Ismail IM, Mostafa TM, Sulaymon AH. Biosorption of heavy metals: A review. J Chem Sci Technol. 2014;3:74-102. 
7. Nasution AN, Amrina Y, Zein R, Aziz H, Munaf E. Biosorption characteristics of $\mathrm{Cd}(\mathrm{II})$ ions using herbal plant of mahkota dewa (Phaleria macrocarpa). J Chem Pharm Res. 2015;7:189-96.

8. Fatriyawan AA, Mahdi C, Aulanniam A, Wuragil D. The Ethanolic extracts therapy of Ceremai leaves (Phyllanthus acidus (L.) Skeels) on malondialdehyde (MDA) levels and histopathology of hepar of hypercholesterolemic rats. Int $\mathrm{J}$ Chem Tech Res. 2016;9:509.

9. Samin B, Fachrial E, Munaf E, Chaidir Z. Adsorption profile of $\mathrm{Cu}(\mathrm{II})$ using soursop (Annona muricata $\mathrm{L}$ ) leaves powder as biosorbent. J Chem Pharm Res. 2015;7:22-7.

10. Amelia L, Jufri M, Munim A. Characterization and safety of Nothopanax scutellarium Ethyl acetate fraction gel ethosome. Int J Pharm Tech. 2016;9(12):432. https://doi.org/10.22159/ ajpcr.2017.v10i8.18866

11. Abdullah Z, Kurniawan MI, Zein R, Aziz H, Munaf E. Prediction of $\mathrm{Pb}(\mathrm{II})$ and $\mathrm{Cu}(\mathrm{II})$ ions biosorption by Annona muricata $\mathrm{L}$. Seeds using artificial neural network (ANN) approach. Res J Pharm Biol Chem Sci. 2013;4(4):1443-51.

12. Ramadhani MR, Bachri MS, Widyaningsih W. Effects of ethanolic extract of arrowroot tubers (Maranta arundinacea L.) on the level of MDA, SGPT and SGOT in ethanol induced rats. Indones
J Med Health J. 2017;8(1):10-8. https://doi.org/10.20885/jkki. vol8.iss1.art3

13. Li S, Tan HY, Wang N, Zhang ZJ, Lao L, Wong CW, et al. The role of oxidative stress and antioxidants in liver diseases. Int J Mol Sci 2015;16(11):26087-124. https://doi.org/10.3390/ ijms161125942 PMid:26540040

14. Ajani EO, Ogunlabi OO, Akinwande O, Adegbesan BO. Loranthus micranthus leaves extract attenuates risk factors of cardiovascular disease in fructose fed rats. Eur $\mathrm{J}$ Med Plants. 2014;1:1489-500.

15. Ginting CN, Fachrial E, Almahdy AA, Yerizel E, Zein R. Protective effect of Sauropus androgynous (L) Merr against toxicity of copper induced oxidative stress and ovary damage in experimental rats. Res J Pharm Biol Chem Sci. 2017;8:1126.

16. Middleton E, Kaswandi C, Theoharides TC. The effects of plants flavonoids on mammalian cells, implications for inflammation, heart disease, and cancer. Pharmacol Rev. 2000;52:711-22.

17. Tchounwou PB, Yedjou CG, Patlolla AK, Sutton DJ. Heavy metal toxicity and the environment. Exp Suppl. 2012;101:133-64.

PMid:22945569 